\title{
Study on the Feasibility and Development Strategy of "Flipped Classroom" in Volleyball Teaching Reform
}

\author{
Liuqing Yang \\ Teaching and Research Section of Physical Education, Heyuan Polytechnic, Guangzhou, 517000, \\ China
}

Keywords: “flipped classroom”; volleyball teaching; research strategy

Abstract: This paper analyzes the advantages of "flipped classroom" and the application of "flipped classroom" in the volleyball course, which may result in problems such as insufficient teacher, the lagging idea and the single form of teaching evaluation. Strategies are proposed. In order to apply the "flipped classroom" mode, it is necessary to change the teacher's concept and judgment form, and improve their own information technology capabilities.

\section{Introduction}

The "Flip Classroom" originated in the United States and is a new form of teaching that has become popular in recent years. Chinese teachers are also exploring how to apply the "Flip Classroom" to the normal course teaching according to the reality. To enhance the students' interest in learning and the quality of teaching, teachers in various schools in the school are exploring how to apply the "flip classroom" teaching form. Of course, physical education teachers are no exception, and they are actively implementing experiments at this level ${ }^{[1]}$.

\section{The superiority of the "flip classroom" teaching form}

\subsection{The teacher's teaching form is more reasonable.}

From the form of flipping classroom teaching, the teacher converts the lessons from the previous class into the class before the class supplies the students with learning resources. After the students reflect the situation before the class, the students from the class must discuss and communicate, and then let the students we control more learning content, as shown in Tables 1 and 2 below: the different designs of the volleyball skills teaching curriculum for the students in the classroom and the traditional classroom teachers:

From the comparison between Table 1 and Table 2, it can be found that in the traditional teaching form, the teacher's individual style and content planning will have a great impact on the teaching results. The teacher mainly finishes the teaching content from the classroom; it is necessary for the students to understand the teaching content before class, and the teacher puts more time on the content of planning the classroom to communicate with each other, so that the classroom time can be used more effectively ${ }^{[2]}$. 
Table 1 Design of the teaching process of students' volleyball skills in the classroom teachers

\begin{tabular}{|c|c|c|}
\hline Before class & Teacher & Student \\
\hline In the class & $\begin{array}{c}\text { Make micro-classes, design } \\
\text { self-study task lists, arrange tasks } \\
\text { volleyball-related skills knowledge, } \\
\text { organize student contact, correct } \\
\text { wrong actions }\end{array}$ & $\begin{array}{c}\text { Self-directed learning can be seen, } \\
\text { volleyball skills contact, feedback } \\
\text { task completion, answer questions }\end{array}$ \\
\hline After class & $\begin{array}{c}\text { Skill consolidation, evaluation of } \\
\text { innovation, teaching evaluation, } \\
\text { adjustment of learning strategies, } \\
\text { formulation of lesson plans, } \\
\text { and exchange }\end{array}$ & $\begin{array}{c}\text { Consolidation of volleyball-related } \\
\text { knowledge, independent inquiry, } \\
\text { cooperation and exchange, } \\
\text { teaching evaluation }\end{array}$ \\
\hline
\end{tabular}

Table 2 Design of the traditional classroom teachers' teaching process for students' volleyball skills

\begin{tabular}{|c|c|c|}
\hline & Teacher & Student \\
\hline Before class & Prepare a lesson plan & Ready to attend class \\
\hline In the class & Brief introduction, layout task & Listen to class, complete the exercise \\
\hline After class & $\begin{array}{c}\text { Complete the lesson plan, teaching } \\
\text { evaluation }\end{array}$ & $\begin{array}{c}\text { Complete the target task, technical } \\
\text { assessment }\end{array}$ \\
\hline
\end{tabular}

\subsection{Enhance the enthusiasm of the students.}

First, flipping the classroom changed the traditional teaching form of knowledge teaching. The teacher used the video to let the students learn independently before the class, so the students changed from the passive learning to the active learning shown in Table 3 below. :

Table 3 Performance and comparison of volleyball special technical assessment

\begin{tabular}{|c|c|c|c|c|}
\hline & Pass & Pad ball & Spike & Serve \\
\hline Control class & $68.5 \pm 2.5$ & $72.5 \pm 3.2$ & $53.4 \pm 2.2$ & $72.6 \pm 3.3$ \\
\hline Experimental class & $72.6 \pm 2.2$ & $83.2 \pm 3.5$ & $56.4 \pm 3.8$ & $81.5 \pm 3.4$ \\
\hline $\mathrm{P}$ & $\mathrm{P}<0.05$ & $\mathrm{P}<0.05$ & $\mathrm{P}>0.05$ & $\mathrm{P}<0.05$ \\
\hline
\end{tabular}

Description:

$\mathrm{N}=81$, $\mathrm{P}$ greater than 0.05 indicates no significant difference in data, and $\mathrm{P}$ less than 0.05 indicates significant difference.

In the traditional form shown in Table 3 above, students usually have different abilities and accepting abilities, which will cause some students to keep up with the teacher's teaching process. From the flipping classroom teaching mode, students can watch the video multiple times. To carry out early practice, improve your understanding of knowledge, and continue to view videos according to your own learning after class to consolidate your knowledge of learning.

From the indicators of the control class and the experimental class, the overall data of the experimental class should be higher than the control class. From the specific indicators in Table 3, it can be seen that the students in the experimental class are more satisfied with the students in the physical education class, the teaching ability, the atmosphere and content of the teaching, and the satisfaction of the classmates. In terms of venue equipment and performance evaluation, the difference between the students in the two classes is not particularly obvious.

- First, for the physical education teachers, the teaching of the flipping classroom mode used in the experimental class not only requires the teachers to prepare for the lesson, but also 
requires the teachers to master the corresponding multimedia software, and to find the production and motion technology related.

- Second, for learners, the "flip" teaching method is a new type of classroom teaching mode, allowing them to take the initiative to watch the video self-study and think independently. The learner's classroom learning atmosphere is more relaxed, and they can learn according to their own situation.

- Third, the students' learning experience in the classroom directly affects the exercise exercises designed by the teachers, and enhances the students' interest in watching and learning, which is quite different from the traditional classroom teaching mode.

- Fourth, under the teaching of flipping classroom mode, teachers guide students to think independently, cooperate with each other, increase communication between students, and enrich after-school life.

- Fifth, when volleyball needs venues, there is only one outdoor volleyball venue in Heyuan Polytechnic College. The rest are all outdoor venues. The sports will be affected by weather, venue equipment, etc. In the flip classroom teaching mode, extracurricular exercises still have certain limitations ${ }^{[3]}$.

\subsection{Teaching resources are more rationalized.}

First, from the flipping classroom teaching form, the teacher can be freed from the classroom. Because the students can learn the content of the teaching before the class, even the students with very poor learning ability can learn many times, so from In the classroom, the teacher cannot repeat the teaching content many times, as shown in Table 4 below, which is the t-test of "flip classroom" under different teaching factors.

Table 4 t-test of "flip classroom" application under different teaching factors

\begin{tabular}{|c|c|c|c|c|c|c|}
\hline & College & $\begin{array}{l}\text { Average } \\
\text { value }\end{array}$ & $\begin{array}{l}\text { Standard } \\
\text { deviation }\end{array}$ & $\mathrm{t}$ & $\mathrm{df}$ & $\mathrm{P}$ \\
\hline \multirow{2}{*}{$\begin{array}{l}\text { Flipping } \\
\text { classroom }\end{array}$} & $\begin{array}{c}\text { Volleyball } \\
\text { professional }\end{array}$ & 16.556 & 1.991 & \multirow{2}{*}{0.981} & \multirow{2}{*}{296} & \multirow{2}{*}{0.327} \\
\hline & $\begin{array}{l}\text { Non-volleyball } \\
\text { major }\end{array}$ & 16.808 & 2.423 & & & \\
\hline \multirow{2}{*}{$\begin{array}{l}\text { Appropriate } \\
\text { participation }\end{array}$} & $\begin{array}{c}\text { Volleyball } \\
\text { professional }\end{array}$ & 23.087 & 2.822 & \multirow{2}{*}{0.578} & \multirow{2}{*}{290} & \multirow{2}{*}{0.564} \\
\hline & $\begin{array}{c}\text { Non-volleyball } \\
\text { major }\end{array}$ & 23.286 & 2.992 & & & \\
\hline \multirow{2}{*}{$\begin{array}{l}\text { Traditional } \\
\text { classroom }\end{array}$} & $\begin{array}{c}\text { Volleyball } \\
\text { professional }\end{array}$ & 6.663 & 2.204 & \multirow[t]{2}{*}{1.747} & \multirow[t]{2}{*}{296} & \multirow[t]{2}{*}{0.082} \\
\hline & $\begin{array}{c}\text { Non-volleyball } \\
\text { major }\end{array}$ & 7.200 & 3.102 & & & \\
\hline
\end{tabular}

In addition to the above Table 4, "Flip Classroom" enhances the sharing of quality resources. Through online teaching, the teaching videos of excellent teachers can be shared, which can make teaching resources play a greater role.

\section{Difficulties that may be encountered in applying "flip classroom" from volleyball classroom teaching}

\subsection{The teacher's ability to apply information technology is not enough.}

In recent years, the faculty of China has continued to improve. From now on, there are many 
schools where volleyball teachers are very proficient in volleyball professional knowledge, but they are not very good at applying message-based teaching. The video level planned and manufactured by computer is still very high. And the network teaching ability is not very strong, but also needs to be upgraded, which seriously restricts the use of flipping classrooms from the volleyball course teaching.

\subsection{The teacher's concept is backward.}

Volleyball teachers are deeply influenced by traditional views, so that they usually feel that only traditional forms of teaching will help to cultivate talents, and students can learn more from teachers. Because the traditional teaching viewpoint has been ingrained, the teachers do not want to change the traditional teaching form, which is not interested in the flipping classroom, and even will have resentment.

\subsection{Teaching evaluation form is single.}

The traditional teaching evaluation is based on the final exam method to judge the students, the form of judgment is relatively simple, and the effect is not very good, and this way is easier to manipulate, the students are also very easy to accept, the volleyball teacher from this level The launch time is relatively small, so the volleyball teacher collectively chooses a relatively mature traditional test method.

\section{Coping strategies for problems in the "flip classroom" of volleyball classroom teaching}

\subsection{Improve the information technology ability of volleyball teachers and build a network digital teaching platform.}

Schools should make full use of their own teaching resources, so that professional audio-visual teachers can teach volleyball teachers. It is necessary to use the "one-on-one" form to enhance the volleyball teacher's information technology ability, that is, an audio-visual teacher teaches a volleyball teacher. It can quickly improve the computer use level of the volleyball teacher. As shown in figure 1 below, the audio-visual teacher's different choices for volleyball teaching can be clearly seen:

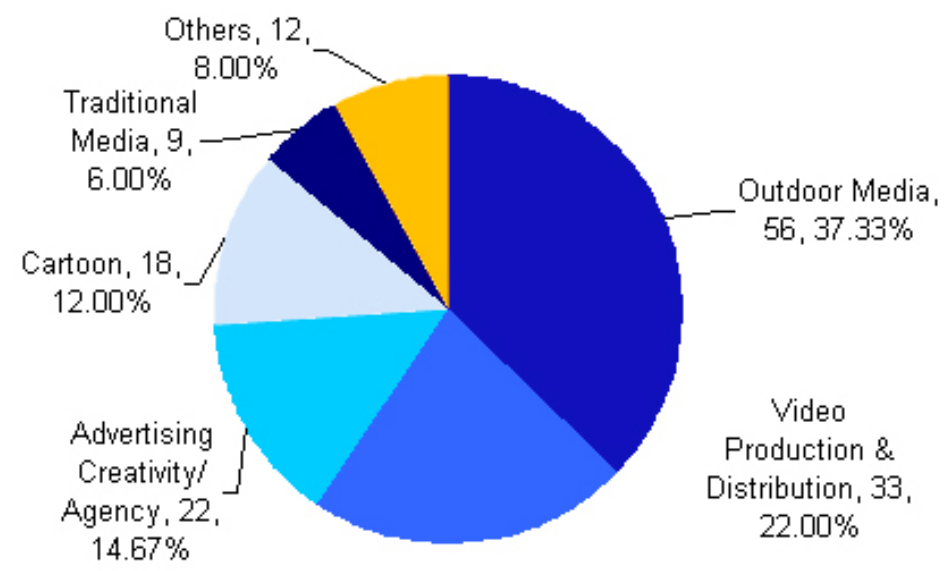

Figure 1 Different choices in the "flip classroom” audio-visual process

Through the analysis of figure 1, we found that the teaching of "Flip the Classroom" should integrate the teachers of the physical education teachers, set up a fine teaching group, develop 
online teaching videos of volleyball classes, and constantly complete teaching materials to build a higher level online teaching platform.

\subsection{Teachers also need to change their mindset.}

From the flipping classroom, the teacher must change the traditional viewpoint, fully demonstrate its main utility and the main utility of the students constantly expand the thinking, and guide the students to learn independently, cooperate and innovate so that the students can truly love the volleyball. Do the master above the class.

\subsection{Change the teaching evaluation mode.}

From the school, teaching evaluation is an important criterion for students to learn. Students regard teaching evaluation as very important. What kind of teaching screen standards are available, students will learn according to the standard, and the test standards are too single. Just paying attention to whether the students' knowledge is already in line with the standards, and not paying attention to the cultivation of the students' own abilities. This is the problem that most of the school volleyball courses have. The teacher of the traditional teaching mode only pays attention to the students. The assessment results, rather than paying attention to the innate quality of the students and the struggles of the day after tomorrow, turning the judgment into a combination of sexual judgment and summative judgment is very helpful to show the advantages of flipping the classroom. Volleyball teachers should promptly explore the judgment. The reasonable methods of the students should not only pay attention to the cultivation of the students' ability, but also let the students enjoy the joy of learning volleyball ${ }^{[4]}$.

\section{Conclusions}

At present, most of the schools have high-quality teachers and teaching teams, audio-visual facilities and technical staff, as well as students with strong comprehension. Only when all the conditions are met, only the software and hardware facilities should be properly applied. It is very feasible to change the viewpoint of volleyball teachers, innovate the teaching evaluation mode, and then use the "flip classroom" mode from the volleyball course.

\section{Acknowledgement}

An Empirical Study on the Development of Sports Clubs in Higher Vocational Colleges for PE Teaching Reform.

\section{References}

[1] Alamidi D F, Smailagic A, Bidar A W, et al. Variable flip angle 3D ultrashort echo time (UTE) T1 mapping of mouse lung: A repeatability assessment [J]. Journal of Magnetic Resonance Imaging, 2018.

[2] Yao S, Zhang J, Zhao Y, et al. Multimodal Image-based Virtual Reality Pre-surgical Simulation and Evaluation for Trigeminal Neuralgia and Hemi-facial Spasm[J]. World Neurosurgery, 2018, 113:S1878875018303401.

[3] Chen $\mathrm{H}, \mathrm{He} X$, Xie G, et al. Cardiovascular magnetic resonance black-blood thrombus imaging for the diagnosis of acute deep vein thrombosis at 1.5 Tesla:[J]. Journal of Cardiovascular Magnetic Resonance, 2018, $20(1): 42$.

[4] Gouttebarge V, Sluis MV, Verhagen E, et al. The prevention of musculoskeletal injuries in volleyball: the systematic development of an intervention and its feasibility [J]. Injury Epidemiology, 2017, 4(1):25. 